\title{
A Comparative Study of Online and Directly Selected Secondary School Teachers Regarding Teaching Proficiency and Classroom Management in Kohat Division, Pakistan
}

\author{
Qaiser Suleman \\ M.Phil (Education), Institute of Education \& Research, Kohat University of Science \& \\ Technology, Khyber Pakhtunkhwa, (Pakistan) \\ Email: Look_for_reality@yahoo.com \\ Dr. Ishtiaq Hussain \\ Assistant Professor, Institute of Education \& Research, Kohat University of Science \& \\ Technology, Khyber Pakhtunkhwa, (Pakistan) \\ Email: dr.ishtiaqkust@gmail.com \\ Ghous-ur- Rehman \\ M.Phil Scholar, Center for Religious Studies, Kohat University of Science \& Technology, \\ Khyber Pakhtunkhwa, (Pakistan)
}

Accepted: March 01, 2013 Published: August 16, 2013

Doi:10.5296/ijld.v3i3.4130 URL: http://dx.doi.org/10.5296/ijld.v3i3.4130

\begin{abstract}
The purpose of this research work was to compare the performance of online and directly selected secondary school teachers regarding teaching proficiency and classroom Management. All the students at secondary school level in Kohat Division, Khyber Pakhtunkhwa (Pakistan) constituted the population of the study. Only 600 students studying at secondary school level in Kohat Division were selected as sample randomly. The study was delimited to only male students at secondary school level. The study was descriptive type and a self-developed structured questionnaire was used as research instrument. Data was collected through personal visits. After collection of data, it was organized, tabulated, analyzed and interpreted. The statistical tools i.e. means, standard deviation and differences of means were computed for each variable. Significance of difference between the mean values of the responses of students about online and directlly selected secondary school teachers were tested at 0.05 levels by applying t-test. After statisitcal analysis of the data, it was conclduded that the overall performance of the directly selected secondary school teachers was better and satisfactory. They were found to have the knowledge of teaching methods and the ability to control classroom disruptive behaviour. Conversely, the overall performance of the online selected secondary school teachers was poor and unsatisfactory. They have no knowledge of
\end{abstract}


teaching methods and subject mastery. They were found unable to manage classroom disruptive behaviour and other related activities. Based on findings, it was strongly recommended that a special professional training programme should be arranged to the existing online selected SSTs in teaching methodologies and classroom management to equip them with the modern teaching methods and techniques of managing classroom disruptive behaviour so that they may become able to perform their duties effectively.

Keywords: Comparative Study, Online Selected SSTs, Directly Selected SSTs, Teaching Proficiency, Classroom Management

\section{Introduction}

Teacher is playing a fundamental and crucial role in the entire education system. Without competent and experienced teachers, education system is meaningless and of no use. The quality of education at any level is directly related to the quality of teachers and their teaching proficiency. But unfortunately, our education system is collapsing day by day due to wrong decisions of higher authorities. Regularization of online selected secondary school teachers is one of the main reasons of collapsing of education system. In 2009, Government of Khyber Pakhtunkhwa recruited secondary school teachers (SSTs) and subject specialists (SSs) for a fixed period of six months through online form without conducting any test or interview. The government intentionally made the in-service teachers deprived from the same recruitment as it was clearly mentioned in the advertisement published in daily Mashriq for in-service teachers to not apply for the same posts as these posts are filled temporarily for a fixed period of time. After completion of the period, they will be discharged from the service. That's why in-service teachers did not apply for these posts. Consequently, non-qualified and inexperienced persons were recruited as SSTs and SSs. But we say with the great regret that Government of Khyber Pakhtunkhwa did not keep her words and the same online selected SSTs and SSs were made regular without devising any criteria for them. These selected SSTs and SSs are known as Online Selected SSTs and SSs. But according to the rules and regulations, they should have to be appointed through Khyber Pakhtunkhwa Public Service Commission because these two posts i.e., SST (BPS-16) and SS (BPS-17) are gazetted posts. Those secondary school teachers who are selected through Provincial Public Service Commission, Khyber Pakhtunkhwa are known as Directly Selected Secondary School Teachers. They are selected through transparent and competitive examination.

No one can deny from the importance and significance of a teacher in education system. According to Deen (2000), the success of any educational system depends upon good and competent teachers. We cannot replace the teachers with any other type of instructional material. It has been well said that the teachers of a school are always better than the system of education; teacher is the basic factor for its success. A teacher is more than what is commonly talked about him. His professional duties have many dimensions. He facilitates students to learn things. Similarly, according to the Government of Pakistan (1979), teachers are the builders of our new generation. Unless we have the most dedicated, hard working and trained teachers in our educational institutions, we cannot educate good citizens for tomorrow. This in turn depends on the effectiveness with which they have been taught by their own 
teachers in the classroom.

The current paper was specially designed to compare the performance of online selected and directly selected secondary school teachers regarding teaching proficiency and classroom management. The findings of the study will update the Government of Khyber Pakhtunkhwa about her wrong and illegal decision of teacher's regularization of the fixed period without devising any criteria for them. The researchers are hopeful that the government will take a constructive action and will refine the existing secondary school teachers through devising special criteria for their regularization. In this way competent and skillful teachers will be the part of education system and will prove beneficial for the development of education system.

\section{Review of Related Literature}

A teacher is a person who provides education for pupils (children) and students (adults). The role and function of a teacher is frequently formal and ongoing, performed at school or other formal educational institution or place. The role of a teacher may differ among cultures. Teachers may provide education in illiteracy and innumeracy, craftsmanship or professional training, religion, the arts, community roles, civics, or life skills and experiences. A teacher is known as a personal tutor who facilitates education for an individual. Teachers assist and facilitate student's learning in school or academy or in any other situation such as outdoors. A teacher is considered as a tutor who provides education on an individual basis to students (Free online Wikipedia). Teachers stand at the crossing point of the transmission of knowledge, skills and values. The culture and tradition of a society is transmitted by a teacher and due to this quality he is considered the builder of the nation (Basit, 2005).

Teacher performance is the most important contribution in the field of education. Whatever policies may be laid down, in the final conclusions and analysis these have to be precious and worthy than the miser's gold and more influential and powerful than the scientist's atomic bomb. Therefore, the teaching profession is very crucial one. It is commonly observed that the school is worth precisely what teacher is worth and due to this reason; improvement in the teacher's education is the first step in any educational reforms (Sliver, 1983). Therefore, it is imperative to pay proper attention on the professional development of teachers in teaching proficiency and classroom management. Effective professional development depends upon the effectiveness of pre-service teachers training programmes. Hence it is suggested that teachers should be trained only through formal teacher training institutes.

Secondary school teachers are those who teach one or more subjects to learners aged thirteen to nineteen. These teachers are considered the backbone of the education system. Therefore, they should possess subject mastery, knowledge of teaching methods, and have control on the classroom disruptive behaviour. They should have to develop the overall personality of the students and understand the psychological basis of education and the 
factors which influence education. According to Suleman, et al (2011a), secondary school teachers play an important and vital role in improving student's characters and academic achievement. That is why these teachers should be able and competent in classroom management, teaching methodologies and knowledge of their subjects. Mohanty (2003) stated that an effective teacher should have control on overall environment of classroom and should possess the abilities and qualities of planning organization and maintaining discipline. Effectiveness of teaching learning process is the product of effective classroom management. Teachers should play a crucial role in improving the environment of classroom, teaching learning process, interaction, control and human relations. The teacher should adopt democracy rather than autocracy. According to Suleman, et al (2012), the success of any educational system depends on good and well-resourced teachers. Teachers cannot be replaced with any other kind of instructional material. It is a fact that teachers are the best in the entire educational system. Therefore, teachers are considered the most important and fundamental factor for the success of any educational system. A teacher is more than what is commonly talked about as his duties of profession have many other dimensions.

It is generally accepted that teachers bring changes and are considered the most important element of educational process as change agent. Therefore, it is right to say that these change agents have to accept greater sense of responsibility to promote strengthened and healthy education. Keeping in view the importance of teachers, the policy makers have always paid their attention on the quality of teachers. In National Education Policy 1978, it was admitted that there is a critical and significant role of teachers in the effective and successful implementation of the education system. It has been accepted that the teacher is the pivot of the entire educational system. In the National Education Policy 1998, it was declared that teachers are the backbone of educational system. In addition, it was stated that effectiveness of education system will be ensured by institutionalizing in-service training of teachers, teacher trainers and educational administrators to build up a viable and practicable structure for planning and development of teacher training programmes, both in-service and pre-service (Almani, 2004; Suleman et al, 2011b).

A review of research on teacher's knowledge and teaching standards recommend that ultimately effective teachers develop the following skills and behaviours:

- Teachers know how to plan, prepare for and devise effective and successful curriculum, assessment tools and instruction strategies.

- Teachers are skillful and competent instructional facilitators.

- Teachers are reflective and insightful practitioners.

- Teachers are professionals dedicated to enduring and life time learning.

- Teachers know how to direct students through course content effectively.

- Teachers know how to judge and evaluate student's performance, how to give effective feedback, and how to apply what they have learned to enhance teaching learning process.

- Teachers know and can use a collection of instructional and communication strategies effectively. 
- Teachers know how to manage classroom environment effectively and how to motivate students.

- Teachers become able to know how children learn and develop effectively.

- Teachers know the subject matter what they have to teach.

- Teachers are skilled and trained in placing, creating, and utilizing curriculum resources and educational technologies.

- Teachers embrace student diversity, understand the community context, and know how to identify the strength and requirements of individual students (Murtaza, 2005).

Communicating or imparting instructions or guiding the students in classroom setting is known as teaching. In wider perspective it means the interaction or communication between the teacher and the taught, preparation of lesson planning, collecting necessary teaching aids and also such activities as assessment of the instruction and communication. Teaching is a very comprehensive and broad term. It consists of not only interaction between the teacher and the student, preparation of lesson plan, utilizing teaching aids, assessment of the instruction but also most of those activities which take place in classroom, at the school, and other activities which are performed at home. Duration of the teaching period, number of students, kinds of teaching activities and interaction between the teacher and the students are different facets of teaching (Zia, 2003). Effective teaching means to adopt a variety of roles depending on the situation. For example, sometimes the performance of the teachers are the most effective and successful way of a performance of the teacher can sometimes be the most effective way of capturing or recapturing the attention and interest of students. However, teachers are more expected to be able to motivate or stimulate learners when they show a real interest in even enthusiasm, for what they are teaching.

Classroom management is a critical part of effective and successful instruction. Effective teaching learning process depends upon effective classroom management. It depends upon the competencies and abilities of teachers. Classroom management is a term used by teachers to describe the process of ensuring that classroom lessons run smoothly and efficiently regardless of disruptive behavior by students. The term also means the prevention of disruptive behavior of the students. It is perhaps the most complicated facet of teaching for many teachers; in fact some teachers leave teaching profession due to this problem (Free online wikipedia). The classroom management is referred to control student, studying in classroom, to manage the teacher and student's behavior and the activity; it is a technique through which a teacher organize what is going on in the classroom. It directly contributes to the efficiency of teaching and learning because most of the effective activities become useless and ineffective if the teacher does not organize them effectively (www.articlesbase.com). The term "Classroom Management" means, "the art of organizing the class". In other words we can say that classroom management is making the atmosphere and situation of the classroom as favorable for teaching as to achieve the required goals and objectives without any loss of time or energy. It involves proper arrangement of working conditions including light, heat and ventilation (Katozai, 2004). Classroom Management is referred to the establishment and maintenance of an environment in which teaching learning process can take place effectively. 
The objective of classroom management is to develop and increase student's learning. Prevention of disruptive behaviours, systematic environment and discipline are all associated issues to classroom management. Thus it means to ensure a courteous, respectful, honest, encouraging atmosphere where students can learn and grow as valuable persons (Basit, 2005). Classroom management is a critical part of effective and successful teaching learning process. Effective classroom management, which sets in motion with well-organized and efficient lesson planning preparation, assists teacher to teach and students to learn. Students do well in an optimistic classroom atmosphere and an environment in which they feel secure, cared for and involved. From a student point of view, effective and successful classroom management provides students with opportunities to socialize while learning interesting content. From a teacher point of view, effective classroom management involves preventive discipline and interesting instruction (Lang and Hebert, 1995).

The terms 'classroom management' and 'discipline' are frequently used interchangeably. However, the term discipline focuses on the disruptive behaviour, ill deeds and punishment. It contains two important limitations. Firstly, discipline highlights on individual rather than classroom and secondly, it indicates only negative behaviour. While, classroom management is the term which is used to highlight all of those positive behaviours and decisions that teachers make to facilitate the learning process of their students. It means all those activities which are imperative to create and maintain systematic learning atmosphere such as planning and preparation of materials, organization, decoration of the classroom and the establishment and implementation of rules and regulations (Tan, Parsons, Hinson, and Sardo-Brown, 2003). According to Krause, et al (2003), classroom management is definitely concerned with behaviour, but it can also be defined more broadly as it involves planning, organization and control of students, the learning process and classroom environment to maintain an effective and successful learning experiences. According to Richards (1990), classroom management refers to the ways and techniques used by a teacher through which he organizes and controls student's behaviour, movement and interaction during a lesson. Classroom management refers to the procedures and routines that are used to keep the daily business of the classroom running smoothly (Teaching Tips, 2005).

A teacher plays a crucial and remarkable role in maintaining effective classroom management. Therefore, a teacher should develop and formulate rules and regulations in order to equip the students with the outcomes of learning and behavioural objectives. According to Foutz, (2005), effective and successful classroom management initiates with the teacher. Therefore the teachers should make a plan so that the learners become able to achieve their learning and behavioral objectives. Basit (2005) stated that a teacher has to create and maintain an environment in classroom that is most contributing and conducive to maximize learning outcomes. In creating better classroom environment, a teacher requires to make an understanding of their students. It includes maximizing the amount of learning, minimizing the behavioral problems and creating an optimistic and safe environment. According to Emmer, et al (1997), good classroom management depends on very careful arrangement of classroom organization, procedures, rules, and instruction. However being 
ready is not sufficient to maintain good behaviour through out the year. You will need to be actively and energetically involved in maintaining student cooperation and obedience with necessary classroom rules and procedures. Sadker and Sadker (1997) stated that good teachers carefully control their classrooms in order to reduce disturbances. They manage to keep all students during the class time, prepare teaching aids, and make it well-located for students to watch the instructional presentations. According to Froyen and Iverson (1999), school and classroom management aims at encouraging and establishing student self-control through a process of promoting positive student achievement and behaviour. Therefore educational attainment, teacher efficiency, teacher and student's behaviour are directly associated with the concept of school and classroom management.

Respect is an important part of classroom management. Therefore, a mutual amount of respect should be developed between the teacher and students before the commencement of any instructional process. The learners should know that there are some rules and regulations to which they are bound to follow to ensure their success. In the same way, teacher must realize that students are not necessarily willing or ready to give value to an instructor without feeling they have reason. Formulation of certain guidelines for the classroom will help in developing respect that is required and thus learners can do their best (www.ehow.com). Order and organization make a classroom run smoothly and efficiently. Having consistent set of procedures and routines will assist the classroom run like a well-oiled machine if the students may familiar with them. Many educational professionals and experts, including Harry Wong and Fred Jones, put emphasis on the significance of having a set of procedures that are followed and revisited from day one. This might include having a procedure for lining up for lunch or handing in papers. Proximity assists teachers in managing what is going on in the classroom. Walking around the room and standing next to students who may be causing a problem will generally do away with the problem quickly. It is important for teachers to know that their standing in one place in the classroom will make students feel as if they are permitted to do what they would like (www.ehow.com).

Seating arrangement in classroom also affects the classroom management. It can be affected by how the seats are arranged in the classroom. The teacher needs to consider about the order of the room and how it will affect what their expectations of the students. For instance, if the teacher decides to put the desks in pairs or groups, they require to be realistic about the reality that there is bound to be some amount of socializing. The seating arrangement also requires to be organized in such a way that the teacher can easily walk around the room and supervise student's behavior. Krause et al (2003) explained that to manage student's behaviour is obviously a complicated process. Teacher must have a variety of skills and abilities to cope with various behaviours in classroom. Different behavioral management techniques and strategies were utilized in classroom. Corporal punishment is one the strategies which is used to control the disruptive behaviour of the students. But, it was not permissible to be used or became the last option in many countries all over the world. Therefore, corporal punishment has been replaced by alternative forms of discipline which ranges from detention, time out, extra written work, behaviour contracts or agreements, 
removal of privileges, in-school suspension and community service to exclusion and expulsion.

Classroom is directly associated to issues of motivation, discipline and respect. Methodologies remain a matter of passionate debate amongst teachers; approaches vary depending on the beliefs of a teacher regarding educational psychology. A large part of traditional classroom management engages in modifying behavior, even though many teachers see using behavioral approaches alone as excessively simplistic. Many teachers formulate a set of rules and procedures at the start of the school year. According to Goodman (2008), through rules and regulations, a student adopts a concrete direction to ensure that our expectations and hopes become a reality. In 1981 the US National Educational Association concluded that $36 \%$ of teachers said that they would perhaps not go into teaching if they had to decide again. A principal reason was "disruptive behaviour of students and discipline" (Free online wikipedia). According to Moskowitz and Hayman (1976), if once a teacher loses control on his classroom, then it becomes increasingly more difficult for them to recover that control (Moskowitz and Hayman, 1976). The time spent in controlling and managing the disruptive behaviour has the unpleasant affect on the academic engagement in the classroom. Most of the class time wastes in maintaining discipline and making environment favorable for instructional process which results in low rate of academic engagement in the classroom. According to Berliner (1988) and Brophy and Good (1986), the time that instructor has to take in correcting disruptive behavior of students caused by poor skills of classroom management results in a lower rate of academic engagement in the classroom.

Suleman et al (2011a) conducted a research study to know the effectiveness of the teaching performance of in-service promoted secondary school teachers in Khyber Pakhtunkhwa (Pakistan), in which they concluded that the teaching performance of in-service promoted secondary school teachers is unfortunately very poor. Majority of the in-service promoted secondary school teachers have no knowledge of teaching methods. They have no relevant pedagogical skills and majority of the students were not satisfied with their teaching methods. They did not use instructional technology in teaching learning process. In a nutshell, their overall teaching performance was far below the levels of satisfaction.

A similar kind of another research study was conducted by Suleman, et al (2011b) to compare the effectiveness of teaching performance of directly selected and in-service promoted secondary school teachers in Khyber Pakhtunkhwa (Pakistan) and concluded that overall teaching performance of the directly selected secondary school teachers was highly appreciable and excellent. They were far better than in-service promoted secondary school teachers because they were fully equipped with teaching methods, knowledge and classroom management. Their overall teaching performance was better than in-service promoted secondary school teachers. Conversely, in-service promoted secondary school teachers did not possess the qualities of an ideal teacher. Their overall performance was poor and unsatisfactory. 


\section{Macrothink Institute ${ }^{\text {tm }}$}

\section{Statement of the Problem}

The study under investigation was specially designed to compare the performance of online and directly selected (through Khyber Pakhtunkhwa Public Service Commission) secondary school teachers. Therefore the statement of the problem was entitled as " $A$ Comparative Study of Online and Directly Selected Secondary School Teachers Regarding Teaching Proficiency and Classroom Management in Kohat Division, Pakistan”.

\section{Objectives of the Study}

The objectives of the study were:

1. to compare online and directly selected secondary school teachers (SSTs) regarding teaching proficiency and classroom management;

2. to identify the weak and strong areas of online and directly selected secondary school teachers (SSTs) regarding teaching proficiency and classroom management; and

3. to suggest workable recommendations to improve the overall performance of secondary school teachers

\section{Research Methodology}

\section{Population}

All the students at secondary school level of public sector in Kohat Division, Khyber Pakhtunkhwa (Pakistan) constituted the population of the study.

\section{Sampling and Sampling Technique}

In order to ensure adequate representation of the population, only 600 students were selected from 60 secondary schools through simple random sampling technique. From each selected secondary school, only 10 students were selected randomly. In this way, 300 students for online selected SSTs and 300 for directly selected SSTs were selected.

\section{Delimitations of the Study}

The study was delimited to 10 secondary schools with online selected SSTs (G) and 10 secondary schools with directly selected SSTs $(\mathrm{G})$ in each district i.e., Kohat, Karak and Hangu of Kohat Division. The study was also delimited to only male secondary schools students and teachers.

\section{Research Instrumentation}

The study was survey type therefore a self-developed structured questionnaire was used as research instrument for data collection. It was composed of 17 closed ended questions which were designed on five point likert scales i.e. SA (Strongly Agree), A (Agree), UN (Undecided), SDA (Strongly Disagree) and DA (Disagree).

\section{Pilot Testing}

Validation and authentication of the research instrument is imperative to achieve exact and precise results. For this purpose, pilot testing was conducted in five secondary schools to 


\section{Macrothink}

International Journal of Learning \& Development

ISSN 2164-4063

2013, Vol. 3, No. 3

eliminate the weaknesses, misconceptions and ambiguities of the questionnaire. So after pilot testing, questionnaire was revised and then its final version was developed in the light of suggestions given by the experts in the field of education.

\section{Validity and Reliability}

It is essential to ensure the trustworthiness of the research and its findings by addressing the issues of validity and reliability. Validity is the degree to which study assess the same concept that the researcher is trying to measure. Validity of the questionnaire was checked by three experts having doctorate degrees in education. Reliability is the degree of consistency that an instrument or data collection procedure demonstrates, while validity is the quality of the collection procedure of the data that enables it to measure what it intends to measure (Best and Kahn, 1998; Gay, 2005; Masrur, 2003). Cronbach's alpha reliability test was used to calculate the reliability of questionnaire. The reliability coefficient was found to be 0.86 for the questionnaire. The following formula was applied:

$$
\alpha=\frac{N \cdot \bar{C}}{\bar{V}+(N-1) \cdot \bar{C}}
$$

Where

$$
\begin{aligned}
& \mathrm{N}=\text { Stands for total number of respondents } \\
& \bar{C}=\text { Stands for average inter-item covariance } \\
& \bar{V}=\text { Stands for average variance }
\end{aligned}
$$

\section{Data Collection}

The researchers personally visited to the respective sample secondary schools and distributed the questionnaires among the participants. Difficult terms were first explained and then the participants were told to give correct response without any hesitation and free of bias. A total of 600 questionnaires were administered and 600 responses were received i.e., 100\% responses. In this way data was collected.

\section{Data Analysis}

After collection of data, it was organized, tabulated, analyzed and interpreted. The statistical tools i.e., means, standard deviation and differences of means were computed for each variable. Significance of difference between the mean score values of the responses of students about online selected and directlly selected SSTs were tested at 0.05 level by applying t-test. The following formulae were used for the statistical analysis of data:

\section{Mean Formula}

Mean of the data was calculated by the following formula:

$$
\text { Mean }=\bar{X}=\frac{\sum f x}{\sum f}
$$


Where $\quad \bar{X}=$ Mean $\quad \mathrm{X}=$ data $\quad \mathrm{f}=$ Frequencies

\section{Standard Deviation Formula}

Standard Deviation of the data was computed by the following formula:

$$
\mathrm{SD}=\sqrt{\frac{\sum X^{2}-\frac{\left(\sum X\right)^{2}}{N}}{N-1}}
$$

Where $\mathrm{N}$ stands for total number of frequencies/respondents

\section{T-Test Formula}

For t-test the following formula was used to calculate the value of $\mathrm{t}$ :

$$
\mathbf{t}=\frac{\overline{X_{1}}-\overline{X_{2}}}{\sqrt{\left(\frac{S S_{1}+S S_{2}}{n_{1}+n_{2}-2}\right)\left(\frac{1}{n_{1}}+\frac{1}{n_{2}}\right)}}
$$

Where $\quad \mathbf{S S}=\sum X^{2}-\frac{\left(\sum X\right)^{2}}{N}$

\section{Analysis of Data and Results}

The study was conducted to compare the performance of online and directly selected secondary school teachers regarding teaching proficiency \& classroom management. The study was descriptive in nature and a self-developed structured questionnaire was used as research instrument for data collection. Data was collected through personal visits. Then it was organized, tabulated, analyzed and interpreted. The statistical tools i.e. means, standard deviation and differences of means were computed for each variable. Significance of difference between the mean score values of the responses of students about online selected and directlly selected SSTs were tested at 0.05 level by applying t-test. The detail is given as under:

Table 01: Your teacher takes his classes regularly.

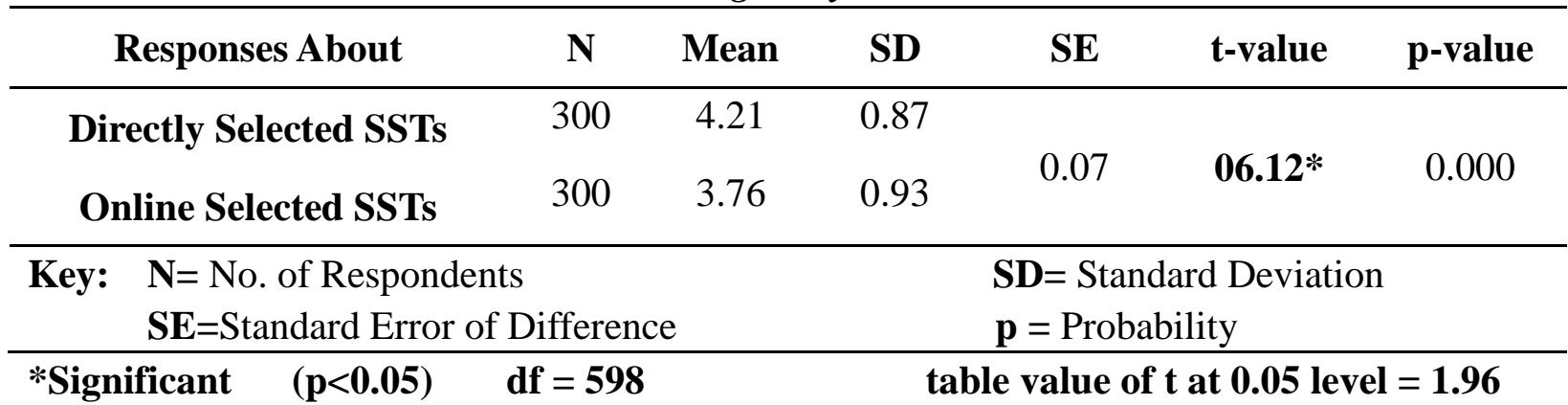

Table 1 illustrates that the calculated value of $t$ was found to be 06.12 which is statistically significant $(\mathrm{p}<0.05)$ because it is greater than the table value of $t$ at 0.05 level. Hence, the mean score values of the responses indicate that directly selected SSTs take their classes more 
regularly as compared to online selected SSTs.

Table 02: Your teacher comes and teaches with full preparation to class.

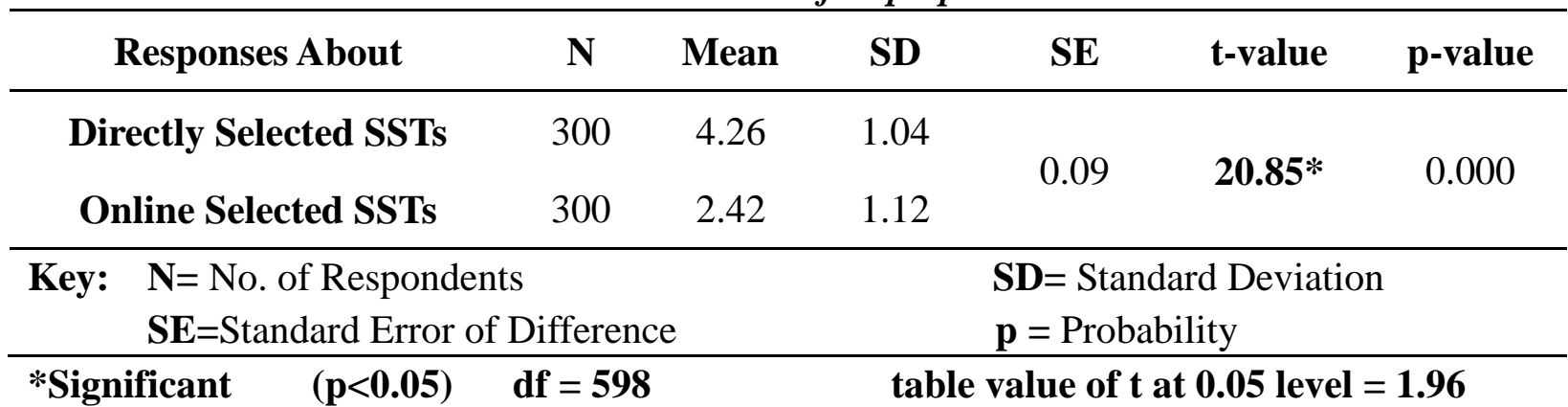

Table 2 indicates that the calculated value of $t$ was found to be 20.85 which is statistically significant $(\mathrm{p}<0.05)$ because it is greater than the table value of $t$ at 0.05 level. Hence, the mean score values of the responses depict that directly selected SSTs always come and teach with full preparation to class as compared to online selected SSTs.

Table 03: You are satisfied with the teaching methods of your teacher.

\begin{tabular}{ccccccc}
\hline Responses About & $\mathbf{N}$ & Mean & SD & SE & t-value & p-value \\
\hline Directly Selected SSTs & 300 & 3.72 & 0.96 & 0.08 & $\mathbf{1 7 . 9 6}^{*}$ & 0.000 \\
Online Selected SSTs & 300 & 2.26 & 1.03 & & & $\begin{array}{l}\text { SD= Standard Deviation } \\
\mathbf{p}=\text { Probability }\end{array}$ \\
\hline Key: $\quad \mathbf{N}=$ No. of Respondents & & \multicolumn{3}{c}{ table value of $\mathbf{t}$ at $\mathbf{0 . 0 5}$ level $=\mathbf{1 . 9 6}$} \\
SE=Standard Error of Difference
\end{tabular}

Table 3 shows that the calculated value of $t$ was found to be 17.96 which is statistically significant $(p<0.05)$ because it is greater than the table value of $t$ at 0.05 level. The mean score values of the responses indicate that students are satisfied with the teaching methods of directly selected SSTs while they are not satisfied with online selected SSTs.

Table 04: Your teacher possesses subject mastery \& knowledge of teaching methods.

\begin{tabular}{ccccccc}
\hline Responses About & N & Mean & SD & SE & t-value & p-value \\
\hline Directly Selected SSTs & 300 & 4.09 & 0.78 & & & \\
Online Selected SSTs & 300 & 2.32 & 0.95 & & & 0.07 \\
\hline
\end{tabular}

\begin{tabular}{lll}
\hline Key: & $\mathbf{N}=$ No. of Respondents & SD= Standard Deviation \\
& SE=Standard Error of Difference & $\mathbf{p}=$ Probability \\
\hline
\end{tabular}

$\begin{array}{llll}* \text { Significant } \quad(p<0.05) & \text { df }=598 \quad \text { table value of } t \text { at } 0.05 \text { level }=1.96\end{array}$

Table 4 indicates that the calculated value of $\mathrm{t}$ was found to be 24.94 which is statistically significant $(\mathrm{p}<0.05)$ because it is greater than the table value of $t$ at 0.05 level. Thus the mean score values of the responses indicate that directly selected SSTs possess subject mastery \& 
knowledge of teaching methods while online selected SSTs do not possess the same.

Table 05: Your teacher assigns you homework daily.

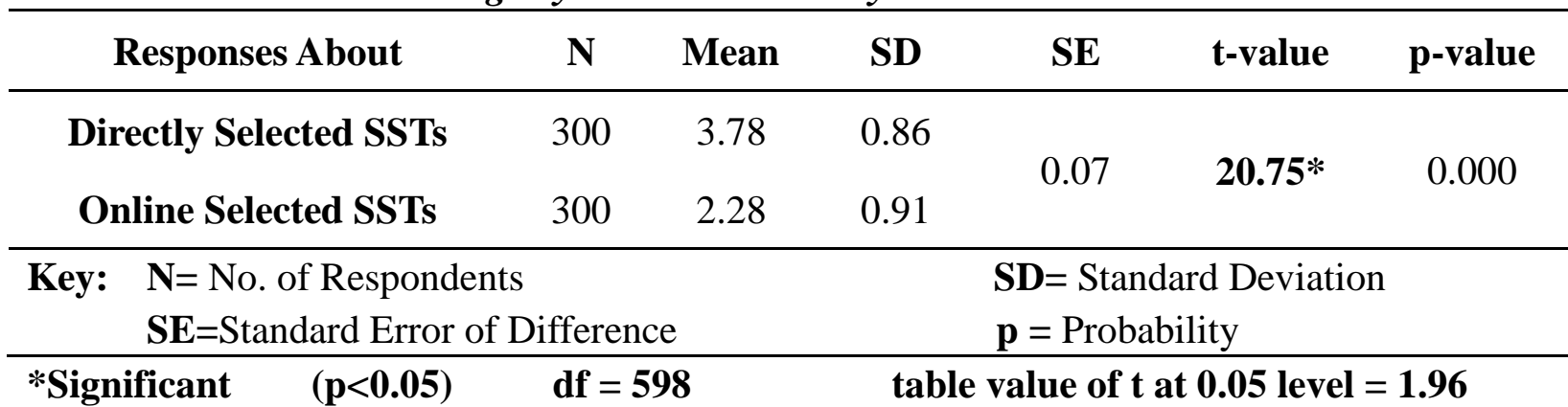

Table 5 shows that the calculated value of $t$ was found to be 20.75 which is statistically significant $(\mathrm{p}<0.05)$ because it is greater than the table value of $t$ at 0.05 level. Hence, the mean score values of the responses indicate that directly selected SSTs assign homework to their students daily while online selected SSTs do not assign homework to students daily.

Table 06: Your teacher checks and evaluates your homework regularly and fairly.

\begin{tabular}{|c|c|c|c|c|c|c|c|}
\hline & esponses About & $\mathbf{N}$ & Mean & SD & SE & t-value & p-value \\
\hline Dir & etly Selected SSTs & 300 & 3.64 & 0.94 & \multirow{2}{*}{0.08} & \multirow{2}{*}{$18.28 *$} & \multirow{2}{*}{0.000} \\
\hline & line Selected SSTs & 300 & 2.16 & 1.04 & & & \\
\hline Key: & $\begin{array}{l}\mathbf{N}=\text { No. of Respond } \\
\mathbf{S E}=\text { Standard Error }\end{array}$ & iffere & & \multicolumn{4}{|c|}{$\begin{array}{l}\text { SD }=\text { Standard Deviation } \\
\mathbf{p}=\text { Probability }\end{array}$} \\
\hline *Sign & $(\mathrm{p}<0.05)$ & $\mathbf{d f}=$ & & $\overline{t a b}$ & of & 05 lev & 96 \\
\hline
\end{tabular}

Table 6 depicts that the calculated value of $t$ was found to be 18.28 which is statistically significant $(p<0.05)$ because it is greater than the table value of $t$ at 0.05 level. Hence, the mean score values of the responses indicate that directly selected SSTs check and evaluate student's homework regularly and fairly while online selected SSTs do not perform the same.

Table 07: Your teacher arranges weekly/monthly test to evaluate and assess the student's academic achievement and performance.

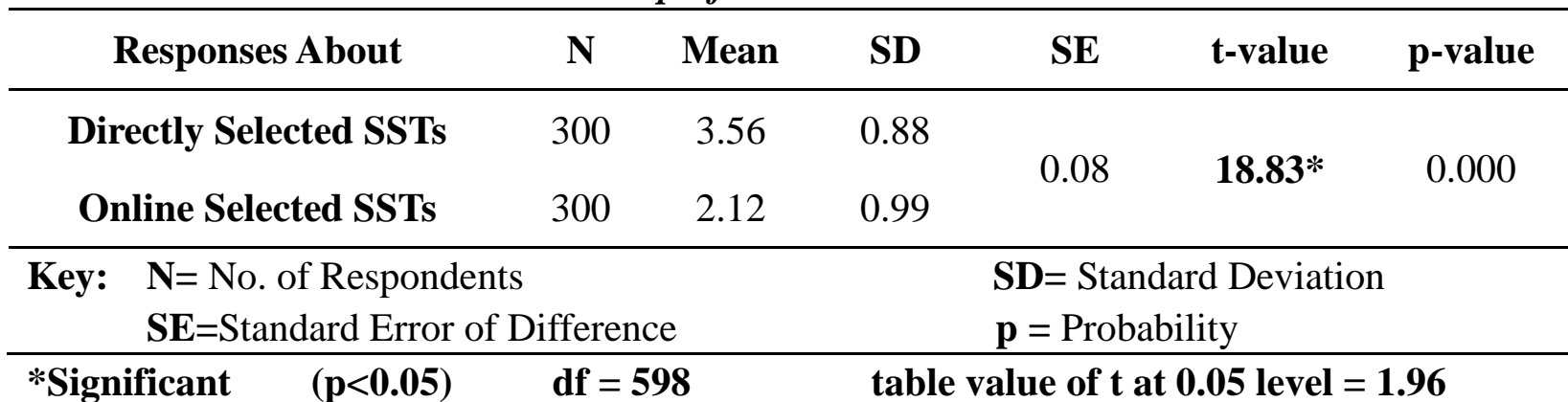

Table 7 indicates that the calculated value of $\mathrm{t}$ was found to be 18.83 which is statistically significant $(p<0.05)$ because it is greater than the table value of $t$ at 0.05 level. Hence, the 
mean score values of the responses indicate that directly selected SSTs arrange weekly/monthly test to evaluate and assess the student's academic achievement and performance while online selected SSTs do not perform the same.

Table 08: Your teacher uses educational technologies i.e. overhead projector, multimedia, models, charts etc for instructional purpose.

\begin{tabular}{|c|c|c|c|c|c|c|c|}
\hline & esponses About & $\mathbf{N}$ & Mean & SD & SE & t-value & p-value \\
\hline Dir & ctly Selected SSTs & 300 & 1.64 & 1.12 & \multirow{2}{*}{0.09} & \multirow{2}{*}{0.867} & \multirow{2}{*}{0.386} \\
\hline & line Selected SSTs & 300 & 1.56 & 1.14 & & & \\
\hline Key: & \multicolumn{3}{|c|}{$\begin{array}{l}\mathbf{N}=\text { No. of Respondents } \\
\mathbf{S E}=\text { Standard Error of Difference }\end{array}$} & & \multicolumn{3}{|c|}{$\begin{array}{l}\text { SD= Standard Deviation } \\
\mathbf{p}=\text { Probability }\end{array}$} \\
\hline
\end{tabular}

Table 8 illustrates that the calculated value of $\mathrm{t}$ was found to be 0.867 which is statistically non-significant $(p>0.05)$ because it is less than the table value of $t$ at 0.05 level. Hence, the mean score values of the responses indicate that both directly selected and online selected SSTs do not use educational technologies i.e. overhead projector, multimedia, models, charts, etc for instructional purpose.

Table 09: Your teacher uses blackboard/whiteboard during teaching learning process regularly.

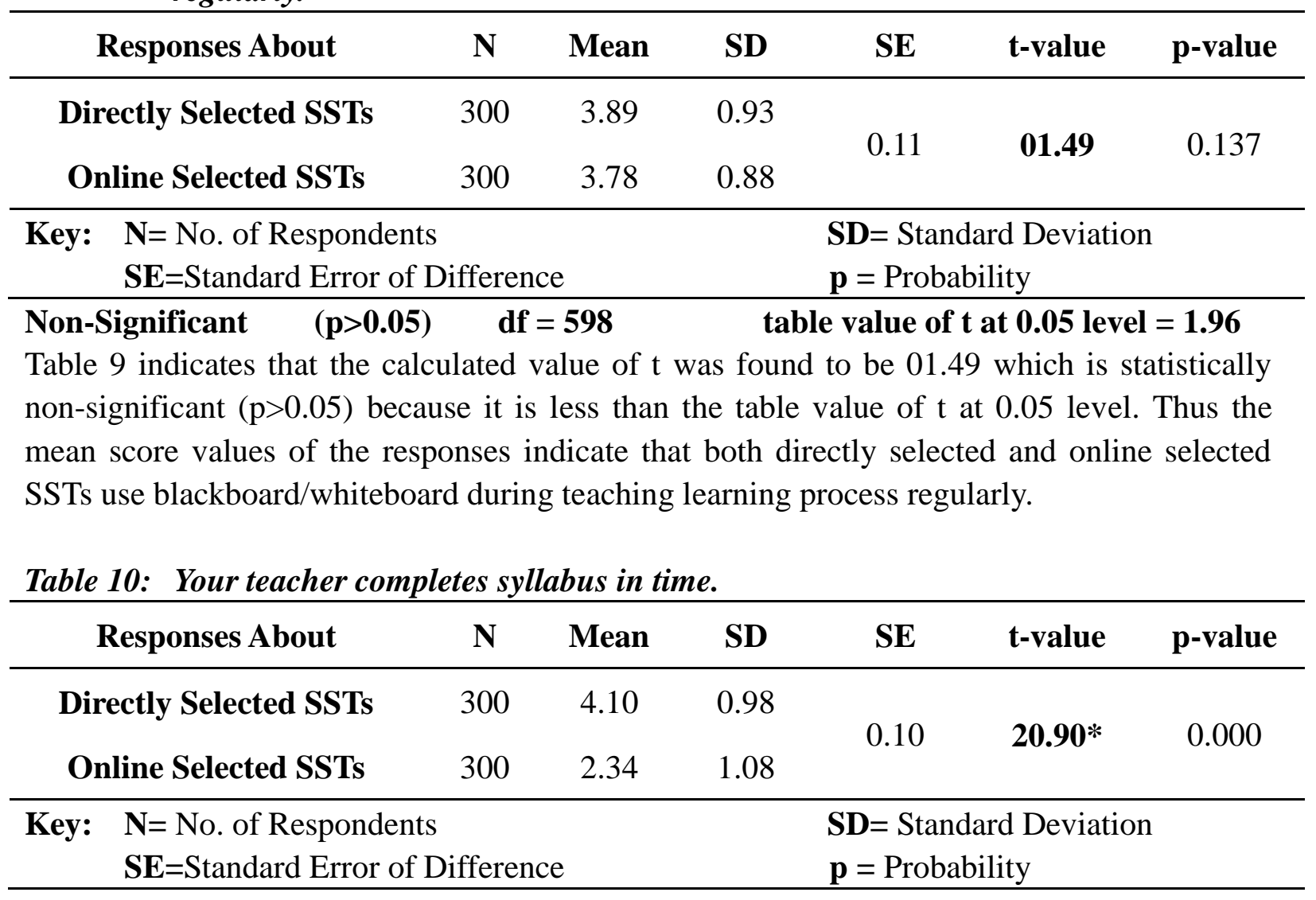


Table 10 shows that the calculated value of $\mathrm{t}$ was found to be 20.90 which is statistically significant $(\mathrm{p}<0.05)$ because it is greater than the table value of $t$ at 0.05 level. Hence the mean score values of the responses indicate that directly selected SSTs complete syllabus in time while online selected SSTs do not complete syllabus in time.

Table 11: At the beginning of the session, teachers formulate and announce classroom rules and regulations to ensure a favorable environment in side the classroom.

\begin{tabular}{ccccccc}
\hline Responses About & N & Mean & SD & SE & t-value & p-value \\
\hline Directly Selected SSTs & 300 & 1.63 & 1.03 & 0.16 & $\mathbf{0 . 7 8 2}$ & 0.435 \\
Online Selected SSTs & 300 & 1.56 & 1.16 & & \\
\hline Key: $\quad \begin{array}{l}\text { N= No. of Respondents } \\
\text { SE=Standard Error of Difference }\end{array}$ & \multicolumn{3}{c}{$\begin{array}{c}\text { p = Probability } \\
\text { table value of } \mathbf{t} \text { at } \mathbf{0 . 0 5} \text { level }=\mathbf{1 . 9 6}\end{array}$}
\end{tabular}

Table 11 indicates that the calculated value of $\mathrm{t}$ was found to be 0.782 which is statistically non-significant ( $p>0.05$ ) because it is less than the table value of $t$ at 0.05 level. Thus the mean score values of the responses indicate that both directly selected and online selected SSTs do not formulate and announce classroom rules and regulations to ensure a favorable environment inside the classroom.

Table 12: Your teacher maintains discipline and has the ability of to manage the disruptive behaviour of the classroom.

\begin{tabular}{|c|c|c|c|c|c|c|c|}
\hline & Responses About & $\mathbf{N}$ & Mean & SD & SE & t-value & p-value \\
\hline Dir & ectly Selected SSTs & 300 & 3.96 & 1.11 & \multirow{2}{*}{0.10} & \multirow{2}{*}{$18.78 *$} & \multirow{2}{*}{0.000} \\
\hline & line Selected SSTs & 300 & 2.25 & 1.12 & & & \\
\hline Key: & \multicolumn{3}{|c|}{$\begin{array}{l}\mathbf{N}=\text { No. of Respondents } \\
\text { SE=Standard Error of Difference }\end{array}$} & & \multicolumn{3}{|c|}{$\begin{array}{l}\mathbf{S D}=\text { Standard Deviation } \\
\mathbf{p}=\text { Probability }\end{array}$} \\
\hline$*$ Sign & $(\mathrm{p}<0.05)$ & df & & & ialue & 0.051 & 1.96 \\
\hline
\end{tabular}

Table 12 depicts that the calculated value of $\mathrm{t}$ was found to be 18.78 which is statistically significant $(\mathrm{p}<0.05)$ because it is greater than the table value of $t$ at 0.05 level. So the mean 
score values of the responses indicate that directly selected SSTs maintain discipline and have the ability of to manage the disruptive behaviour of the classroom while online selected SSTs do not posses the same ability to maintain discipline in classroom.

Table 13: Your teacher applies the principles of educational psychology in the classroom.

\begin{tabular}{ccccccc}
\hline Responses About & N & Mean & SD & SE & t-value & p-value \\
\hline Directly Selected SSTs & 300 & 3.48 & 0.99 & 0.13 & $\mathbf{2 0 . 6 7 *}$ & 0.000 \\
Online Selected SSTs & 300 & 1.74 & 1.07 & & \\
\hline Key: $\quad \mathbf{N}=$ No. of Respondents & & & $\begin{array}{l}\text { SD= Standard Deviation } \\
\text { p = Probability }\end{array}$ \\
SE=Standard Error of Difference & table value of $\mathbf{t}$ at $\mathbf{0 . 0 5}$ level $=\mathbf{1 . 9 6}$
\end{tabular}

Table 13 indicates that the calculated value of $\mathrm{t}$ was found to be 20.67 which is statistically significant $(p<0.05)$ because it is greater than the table value of $t$ at 0.05 level. Hence the mean score values of the responses of students indicate that directly selected SSTs apply the principles of educational psychology in the classroom while online selected SSTs do not apply the same.

Table 14: Your teacher pays his attention individually to each student properly.

\begin{tabular}{ccccccc}
\hline Responses About & N & Mean & SD & SE & t-value & p-value \\
\hline Directly Selected SSTs & 300 & 4.06 & 0.89 & 0.11 & $\mathbf{2 1 . 0 2 *}$ & 0.000 \\
Online Selected SSTs & 300 & 2.38 & 1.06 & & \\
\hline Key: $\quad \begin{array}{c}\text { N= No. of Respondents } \\
\text { SE=Standard Error of Difference }\end{array}$ & \multicolumn{3}{c}{$\begin{array}{l}\text { p = Probability } \\
\text { *Significant } \quad(\mathbf{p}<\mathbf{0 . 0 5}) \quad \mathbf{d f}=\mathbf{5 9 8}\end{array}$}
\end{tabular}

Table 14 illustrates that the calculated value of $t$ was found to be 21.02 which is statistically significant $(p<0.05)$ because it is greater than the table value of $t$ at 0.05 level. So the mean score values of the responses indicate that directly selected SSTs pay their attention individually to each student while online selected SSTs do not pay their attention individually to each student.

Table 15: Your teacher keeps in mind student's individual differences while teaching in the classroom.

\begin{tabular}{ccccccc}
\hline Responses About & N & Mean & SD & SE & t-value & p-value \\
\hline Directly Selected SSTs & 300 & 4.09 & 0.96 & & & \\
Online Selected SSTs & 300 & 2.42 & 1.09 & & $\mathbf{1 9 . 9 1 *}$ & 0.000 \\
\hline
\end{tabular}


Key: $\mathbf{N}=$ No. of Respondents 2013, Vol. 3, No. 3 $\mathrm{SE}=$ Standard Error of Difference

SD $=$ Standard Deviation

*Significant $\quad(\mathbf{p}<0.05) \quad$ df $=598$ $\mathbf{p}=$ Probability

Table 15 depicts that the calculated value of $t$ was found to be 19.91 which is statistically significant $(\mathrm{p}<0.05)$ because it is greater than the table value of $t$ at 0.05 level. Hence the mean score values of the responses indicate that directly selected SSTs keep in mind student's individual differences during teaching while online selected SSTs do no keep in mind student's individual differences during teaching.

Table 16: Your teacher pays proper attention on cleanliness in the classroom.

\begin{tabular}{ccccccc}
\hline Responses About & N & Mean & SD & SE & t-value & p-value \\
\hline Directly Selected SSTs & 300 & 3.98 & 0.87 & 0.08 & $\mathbf{2 3 . 5 1 *}$ & 0.000 \\
Online Selected SSTs & 300 & 2.16 & 1.02 & & \\
\hline Key: $\quad \mathbf{N}=$ No. of Respondents & \multicolumn{3}{c}{$\begin{array}{l}\text { SD= Standard Deviation } \\
\mathbf{p}=\text { Probability }\end{array}$} \\
SE=Standard Error of Difference & \multicolumn{3}{c}{ table value of $\mathbf{t}$ at $\mathbf{0 . 0 5}$ level = 1.96 }
\end{tabular}

Table 16 shows that the calculated value of $t$ was found to be 23.51 which is statistically significant $(\mathrm{p}<0.05)$ because it is greater than the table value of $t$ at 0.05 level. Thus the mean score values of the responses indicate that directly selected SSTs pay proper attention on cleanliness in the classroom while online selected SSTs do not pay proper attention on cleanliness.

Table 17: Your teacher manages student's seating arrangement properly.

\begin{tabular}{|c|c|c|c|c|c|c|c|}
\hline & esponses About & $\mathbf{N}$ & Mean & SD & SE & t-value & p-value \\
\hline Direc & ly Selected SSTs & 300 & 4.12 & 0.94 & \multirow{2}{*}{0.08} & \multirow{2}{*}{$21.42 *$} & \multirow{2}{*}{0.000} \\
\hline Onlin & Selected SSTs & 300 & 2.34 & 1.09 & & & \\
\hline Key: & \multicolumn{3}{|c|}{$\begin{array}{l}\mathbf{N}=\text { No. of Respondents } \\
\mathbf{S E}=\text { Standard Error of Difference }\end{array}$} & & \multicolumn{3}{|c|}{$\begin{array}{l}\text { SD }=\text { Standard Deviation } \\
\mathbf{p}=\text { Probability }\end{array}$} \\
\hline
\end{tabular}

Table 17 indicates that the calculated value of $\mathrm{t}$ was found to be 21.42 which is statistically significant $(\mathrm{p}<0.05)$ because it is greater than the table value of $t$ at 0.05 level. Hence, the mean values of the responses indicate that directly SSTs manage student's seating 
arrangement properly while online selected SSTs do not manage student's seating arrangement properly.

\section{Findings and Conclusions}

After statistical analysis of the data, the following findings were drawn:

It was found that;

1. Directly SSTs take their classes more regularly as compared to the online selected SSTs.

2. Directly selected SSTs always come and teach with full preparation to class while online selected SSTs do not perform the same effectively.

3. Students are satisfied with the teaching methodologies of directly selected SSTs while they are not satisfied with the teaching methods of online selected SSTs.

4. Directly selected SSTs possess subject mastery \& knowledge of teaching methods while online selected SSTs do not possess the same.

5. Directly selected SSTs assign homework to their students daily while online selected SSTs do not assign homework to students daily.

6. Directly selected SSTs check and evaluate student's homework regularly and fairly while online selected SSTs do not perform the same.

7. Directly selected SSTs arrange weekly/monthly test to evaluate and assess the student's academic achievement and performance while online selected SSTs do not perform the same regularly.

8. Both directly selected and online selected SSTs do not use educational technologies i.e. overhead projector, multimedia, models, charts etc for instructional purpose.

9. Both directly selected and online selected SSTs use blackboard/whiteboard during teaching learning process.

10. Directly selected SSTs complete syllabus in time while online selected SSTs do not complete syllabus in time.

11. Directly selected SSTs maintain discipline and have the ability of to manage the disruptive behavior of the classroom while online selected SSTs do not posses the ability to maintain discipline and control disruptive behavior of the classroom.

12. Directly selected SSTs apply the principles of educational psychology in the classroom while online selected SSTs do not apply the same.

13. Directly selected SSTs pay their attention individually to each student properly while online selected SSTs do not pay their attention individually to each student.

14. Directly selected SSTs keep in mind student's individual differences during teaching while online selected SSTs do no keep in mind student's individual differences during teaching.

15. Directly selected SSTs pay proper attention on cleanliness in the classroom while online selected SSTs do not pay proper attention on cleanliness.

16. Directly SSTs manage student's seating arrangement properly while online selected SSTs do not manage student's seating arrangement properly.

Weak and Strong Areas of the Directly Selected Secondary School Teachers Regarding 


\section{Macrothink

Teaching Performance \& Classroom Management

\section{Strong Areas}

It was found that:

- Directly SSTs take their classes more regularly.

- They always come and teach with full preparation to class.

- They possess subject mastery \& knowledge of teaching methods.

- They assign homework to their students daily.

- They check and evaluate student's homework regularly and fairly.

- They arrange weekly/monthly test to evaluate and assess the student's academic achievement and performance.

- They complete syllabus in time.

- They do not formulate and announce classroom rules and regulations at the start of session to ensure a favorable environment inside the classroom.

- They maintain discipline and have the ability of to control the disruptive behavior of the classroom.

- They apply the principles of educational psychology in the classroom.

- They pay their attention individually to each student.

- They keep in mind student's individual differences during teaching.

- They pay proper attention on cleanliness in the classroom. Majority of the students are satisfied with the teaching methods of directly selected SSTs.

- They manage student's seating arrangement properly.

\section{Weak Areas}

It was found that:

- Directly selected secondary school teachers do not use educational technologies i.e. overhead projectors, televisions and radios for instructional purpose.

- They do not formulate and announce classroom rules and regulations at the beginning of new session to ensure a favorable environment inside the classroom

Weak and Strong Areas of the Online Selected Secondary School Teachers Regarding Teaching Performance \& Classroom Management

\section{Strong Areas}

It was found that:

- Online selected secondary school teachers use black/whiteboard during teaching learning process.

- They take their classes regularly.

\section{Weak Areas}

It was found that:

- Online selected SSTs do not come and teach with full preparation to class.

- They do not possess subject mastery \& knowledge of teaching methods.

- They do not assign homework to their students daily. 
- They do not check and evaluate student's homework regularly and fairly.

- They do not arrange weekly/monthly test to evaluate and assess the student's academic achievement and performance.

- They do not complete syllabus in time.

- They do not maintain discipline and have not the ability of to control the disruptive behavior of the classroom.

- They do not formulate and announce classroom rules and regulations at the beginning of new session to ensure a favorable environment inside the classroom

- They do not apply the principles of educational psychology in the classroom.

- They do not pay their attention individually to each student.

- They do not keep in mind student's individual differences during teaching.

- They do not pay proper attention on cleanliness in the classroom. Students are not satisfied with the teaching methods of online selected SSTs.

- They do not manage student's seating arrangement properly.

\section{Concluding Remarks}

In nutshell, it was concluded that the overall performance of the directly selected secondary school teachers are better and satisfactory. They possess subject mastery; knowledge of teaching methods and educational psychology; and ability to maintain classroom disruptive behaviour and management. On the other hand, the overall performance of the online selected secondary school teachers regarding teaching proficiency and classroom management was poor and disappointing at all.

\section{Recommendations}

Keeping in view the findings and conclusions, the researchers make some recommendations which are explained as under:

1. As the study revealed that the overall performance of the online selected secondary school teachers is poor and unsatisfactory. They have lack of subject mastery and knowledge of teaching methods. They have no ability to maintain discipline and to control the disruptive behaviour of the classroom. It means they are illegible as a secondary school teacher. Therefore it is strongly recommended that a decisive transparent and competitive examination should be arranged through Khyber Pakhtunkhwa Public Service Commission for online SSTs and those SSTs should be dismissed from the service who failed the same examination.

2. According to the contemporary service structure of teachers, $50 \%$ in-service teachers are promoted to SSTs from the different teaching cadre i.e., C.T, D.M, P.E.T, T.T, and A.T; which is harmful and damaging to the quality of education. Therefore it is strongly recommended that at least $75 \%$ appointments of the SSTs should be selected through direct transparent and competitive examination in order to ensure the quality of education at secondary level.

3. As the study revealed that online selected SSTs are not proficient in teaching and classroom management therefore, it is strongly recommended that special professional training programme should be arranged to the existing online selected SSTs in 
teaching methods and classroom management in order to equip them with the modern teaching methodologies and techniques of managing classroom behaviour so that they become able to perform their duties effectively.

4. As the study exposed that both directly selected and online selected SSTs do not utilize educational technology during teaching learning process. There are two main reasons of not utilizing educational technologies i.e., poor availability of educational technology and lack of training. Therefore it is strongly recommended that a special training programme should be launched to train secondary school teachers in utilizing educational technologies. In addition, educational technology i.e. overhead projectors, multimedia, educational televisions, radios, DVD players, models etc should be provided to each school immediately.

5. Online selected SSTs are directed to pay their proper attention to maintain discipline and to control the disruptive behaviour of the classroom in order to ensure effective teaching learning process. In addition, they should pay their attention to ensure cleanliness and proper seating arrangement of the students.

6. It is also recommended that online selected SSTs should arrange weekly test for the assessment of the student's academic achievement. Further they are advised to come to class with full preparation.

7. It is strongly recommended that at the beginning of new session, classroom management rules and regulations should be formulated and announced so that students may understand the conduct of a teacher.

8. Surprising visits of the higher authorities should be made in order to evaluate the teaching performance of the secondary school teachers.

9. Proper annual inspection programme should be implemented effectively in order to evaluate the overall performance of teachers.

10. In-service training should be provided especially to all online selected and in-service promoted SSTs on professional skills at least once in every two years to equip them with the modern teaching techniques so that they may perform their duties effectively.

11. Special refresher short courses should be introduced for SSTs especially for online selected and in-service promoted SSTs to enhance their teaching efficiency and productivity.

12. It is also recommended that this type of research study should be conducted in other districts and provinces. Further it is recommended that the performance of online selected and directly selected subject specialists (SSs) should be compared.

\section{References}

Almani, A. S. (2004). Comparative Study of Effects of In-Service and the Performance of Secondary School Teachers. Ph.D Thesis, Department of Education and Social Sciences, Hamdard University. pp. 3, 82-83

Barbetta, P., Norona, K. and Bicard, D. (2005). Classroom Behavior Management: A dozen common mistakes and what to do instead. Preventing School Failures, 49 (3), 11-19.

Basit, A. (2005). Classroom Management Techniques at Secondary Level and Developing a Model for Urban Schools for District Peshawar. M.Phil Thesis, Allama Iqbal Open 
University, Islamabad. p. 19

Bear, G. G. (2008). Best Practices in Classroom Discipline. In Thomas, A. and Grimes, J. (Eds.), Best Practices in School Psychology V (1403-1420). Bethesda, MD: National Association of School Psychologists.

Bear, G. G., Cavalier, A. and Manning, M. (2005). Developing Self-Discipline and Preventing and Correcting Misbehavior. Boston: Allyn and Bacon.

Berliner, D. C. (1988). Effective Classroom Management and Instruction: A knowledge base for consultation. In J. L. Graden, J. E. Zins, and M. J. Curtis (Eds.), Alternative educational delivery systems: Enhancing instructional options for all students (pp.309-325). Washington, DC: National Association of School Psychologists.

Best, J. and Kahn, J. (1998). Research in education (8th ed.). Boston: Allyn and Bacon.

Brophy, J. E., and Good, T. L. (1986). Teacher Behavior and Student Achievement. In M. C. Wittrock (Ed.), Handbook of research on teaching (3rd ed., pp. 328-375). New York: Macmillan.

Carolyn M. E and Carol, S. (2006). Handbook of Classroom Management: Research, Practice, and Contemporary Issues. Mahwah, N.J: Lawrence Erlbaum Associates. ISBN 0-8058-4753-7.

Emmer, F. T., Evertson, M. C., Clements, S. B. and Worshan, F. M. (1997). Classroom Management for Secondary Teacher (4 ${ }^{\text {th }}$ Edition). USA: Viacom Company. p.111

Foutz, A. (2005). Classroom Management Plan. Downloaded from httpllwww.calstatela. edu/faculty/classmgmt.html

Froyen, L. A. and Iverson, A. M. (1999). School Wide and Classroom Management: The reflective educator-leader (3rd ed.). Upper Saddle River, NJ: Prentice-Hall.

Gay, L. R. (2005). Educational research: Competencies for analysis and application. Islamabad: National Book Foundation.

Goodman, M. E. (2008). The Caring Teacher's Guide to Discipline: Helping students Learn Self-Control, Responsibility, and Respect, K-6. 2008, p.36

Government of Pakistan. (1979). The Education Policy 1979. Ministry of Education Islamabad.

Katozai, M. A. (2004). Preparation for the PCS Screening Test of Senior English Teacher. University Publishers Shop \# 8 - A Afghan Market, Qissa Khwani Peshawar. p. 119

Kauchak, D. and Eggen, P. (2008). Introduction to Teaching: Becoming a professional (3rd ed.). Upper Saddle River, NJ: Pearson Education, Inc.

Krause, K. L., Bochner, S., and Duchesne, S. (2003). Educational Psychology for Learning and Teaching. Australia: Thomson.

Lang, R. H. and Hebert, J. (1995). Teaching Strategies and Methods for Students Centered Instruction. America: Whiney, H.M.

Masrur, R. (2003). Thesis writing: A systematic approach. Islamabad: Allama Iqbal Open University.

Mohanty, J. (2003). Teacher Education. New Delhi: Deep and Deep Publications. p.210

Moskowitz, G., and Hayman, J. L., Jr. (1976). Success Strategies of Inner-City Teachers: A year-long study. Journal of Educational Research, 69, 283-289. 
Murtaza, A. (2005). Comparative Study of Teaching Practice in Formal and Non-Formal Systems and Development of a Model. Ph.D Thesis, University Institute of Education and Research, University of Arid Agriculture, Rawalpindi-Pakistan. pp. 27-28

Richards (1990). Cited in Encyclopedic Dictionary of Applied Linguistics, edited by Keith Johnson and Helen Johnson.

http://www.blackwellreference.com/public/tocnode?id=g9780631214823_chunk_g9 806312148237_ss1-12

Sadker, M. and Sadker, D. M. (1997). Teachers, Schools, and Society (4th Edition): McGraw-Hill (New York) Book (ISBN 0070577846)

Silver. (1983). Educational Administration. Harper and Row Publishers. New York. p.113

Suleman, Q., Aslam, H. D., Habib, M. B, Javed, T. and Umbrin, S. (2011a). Evaluative Study of the Effectiveness of Teaching Performance of In-Service Promoted Secondary School Teachers in Khyber Pakhtunkhwa (Pakistan). International Journal of Humanities and Social Science, 1 (14); 136-149

Suleman, Q, Aslam, H. D, Sarwar, S. and Shabbir, F. (2011b). Effectiveness of Educational Technology in Teaching Chemistry to Secondary School Students in Khyber Pakhtunkhwa (Pakistan). American Journal of Scientific Research, Issue 41, 115-131 http://www.eurojournals.com/ajsr.htm

Suleman, Q., Aslam, H. D, Hussain, I. and Ahmad, S. (2012). Identification of the Problems Faced by Secondary School Teachers in District Karak (Pakistan). International Journal of Learning and Development, 2 (5), 324-338

Tan O. S., Parsons, R. D., Hinson, S. L., and Sardo-Brown, D. (2003). Educational Psychology: A Practitioner-Researcher Approach. Australia: Thomson.

Teaching Tips.com (2005). Class Management: Ideas to Inspire and Support Teachers. Downloaded form http://www.teachingtips.com/articles/Xclassmgmt.html

Tingstrom, D. H., Sterling-Turner, H. E. and Wilczynski, S. M. (2006). The Good Behavior Game: 1969-2002. Behavior Modification, 30, 2, 225-253.

Zia, M. A. (2003). English Compulsory B.Ed. Allama Iqbal Open University Islamabad. p. 321

Websites used:

- http://www.ehow.com/about_5438989_classroom-management-definition.html

- http://www.ehow.com/info_7990128_factors-affecting-classroom-management.html

- http://en.wikipedia.org/wiki/Classroom_management

- http://www.ehow.com/about_5438989 classroom-management-definition.html

- eHow.com http://www.ehow.com/about_5438989_classroom-management-definition. html\#ixzz2CdgsWiSP

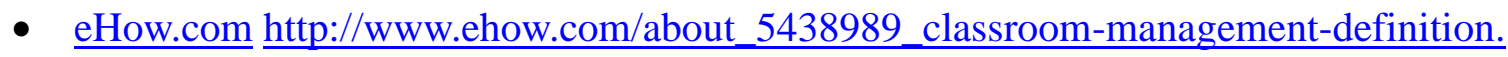
html\#ixzz2Cdgf0Eh3

- http://www.prospects.ac.uk/secondary_school_teacher_job_description.htm

- http://www.blackwellreference.com/public/tocnode?id=g9780631214823_chunk_g97 806312148237_ss1-12

- http://www.articlesbase.com/literature-articles/the-concept-of-classroom-management

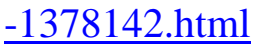

